\title{
PENGARUH PEMBERIAN TEKNIK RELAKSASI GUIDED IMAGERY TERHADAP TINGKAT KECEMASAN PADA PASIEN PRE OPERASI SECTIO CAESAREA DI RSUD dr. R. SOEDJONO SELONG
}

\author{
I Gusti Ayu Mirah Adhi' ${ }^{1}$, Teguh Gama Zarkasyi ${ }^{2}$, Alwan Wijaya ${ }^{3}$, \\ I Made Eka Santosa ${ }^{4}$ \\ 1,2,3,4) Sekolah Tinggi IlmuKesehatan Mataram (STIKES) Mataram \\ gustiayumirahadhi@gmail.com
}

\begin{abstract}
ABSTRAK
Latar belakang: Setiap ibu menginginkan persalinannya berjalan lancar dan dapat melahirkan bayi dengan sempurna. Persalinan bisa saja berjalan secara normal, namun tidak jarang proses persalinan mengalami hambatan dan harus dilakukan melalui operasi. Sectio caesarea adalah salah satu operasi bedah yang paling umum dilakukan di dunia saat ini sebagai salah satu cara untuk membantu proses kelahiran janin melalui insisi pada dinding abdomen (laparotomi) dan dinding rahim (histerektomi). Perasaan cemas ibu yang akan mejalani sectio caesarea merupakan hal yang wajar, tetapi jika tidak diatasi segera akan mempengaruhi ibu dan janin baik fisik maupun psikis. Tujuan dari penelitian ini untuk mengetahui pengaruh pemberian guided imagery terhadap tingkat kecemasan pada pasien pre operasi sectio caesarea.

Metodologi: Desain penelitian ini adalah jenis pre-eksperimental design dengan one group pre-test \& post-test. Populasi dalam penelitian ini adalah seluruh ibu hamil yang akan melakukan operasi sectio caesarea di RSUD dr. R. SOEDJONO SELONG sebanyak 34 responden. Sampel dalam penelitian ini adalah ibu hamil primigravida yang akan melakukan operasi sectio caesarea sebanyak 31 orang responden. Teknik pengambilan sampel dengan purposive sampling. Teknik pengumpulan data menggunakan kuesioner, dan analisa data menggunakan uji Wilcoxon signed test.

Hasil: Berdasarkan hasil penelitian ini sebagian besar responden berusia 26-35 tahun (64.5\%) dengan rata-rata tingkat pendidikan SMA (29.1\%) dan terdapat perbedaan tingkat kecemasan antara pre-test dan post-test yaitu tingkat kecemasan sesudah diberikan perlakuan lebih rendah dibandingkan sebelum diberikan perlakuan.

Simpulan: Simpulan dari penelitian ada pengaruh pemberian guided imagery terhadap tingkat kecemasan pada pasien pre operasi sectio caesarea. Teknik relaksasi guided imagery dapat dijadikan sebagai terapi non farmakologi untuk mengurangi kecemasan yang dirasakan oleh ibu yang akan melakukan operasi sectio caesarea.
\end{abstract}

Kata kunci: guided imagery, sectio caesarea, tingkat kecemasan

THE EFFECT OF PROVIDING IMAGE RELAXATION TECHNIQUES ON ANXIETY LEVELS IN PRE-OPERATIONS SECTIO CAESAREA PATIENT IN RSUD dr. R. SOEDJONO SELONG

\section{Teguh Gama Zarkasyi ${ }^{1}$, I Gusti Ayu Mirah Adhi², Alwan Wijaya ${ }^{2}$, I Made Eka Santosa ${ }^{2}$}

${ }^{1}$ Student @ Mataram College of Health Sciences

${ }^{2}$ Lecturer@Mataram College of Health Sciences 


\section{Email: gamateguh98@gmail.com gustiayumirahadhi@gmail.com alwanwijaya2121@gmail.com imadeekasantosa@gmail.com}

\begin{abstract}
Background: Every mother wants a smooth delivery and can deliver a perfect baby. Childbirth can go on normally, but It is common for the delivery process to experience obstacles and must be done through surgery. Sectio Caesarea is one of the most common surgical operations performed in the world today as a way to assist in the delivery of the fetus through incisions in the abdominal wall (laparotomy) and the uterine wall (hysterectomy). The feeling of anxiety from the mother who is going to undergo a caesarean sectio is normal, but if it is not going well, it will immediately affect the mother and the fetus, both physically and psychologically.

The purpose of this study was to determine the effect of guided imagery on anxiety levels in preoperative Sectio Caesarean patients.

Methodology: This research design is a type of pre-experimental design with one group pre-test and post-test. The population in this study was all pregnant women who will undergo sectio Caesarea surgery at RSUD dr. R. SOEDJONO SELONG, as many as 34 respondents. The sample in this study was 31 primigravida pregnant women who will undergo sectio Caesarea surgery as many as 31 respondents. The sampling technique was purposive sampling. Data collection techniques using a questionnaire, and data analysis using the Wilcoxon signed test.

Results: Based on the results of this study, Most of the respondents attain the age of 2635 years (64.5\%) with an average level of high school education (29.1\%). There was a difference in anxiety levels between the pre-test and post-test, namely the level of anxiety after being given treatment was lower. compared before being given treatment.

Conclusion: This study concludes that there is an effect of providing guided imagery on the level of anxiety in patients with preoperative Sectio Caesarea. Therefore, the guided imagery relaxation technique can be used as a non-pharmacological therapy to reduce the anxiety felt by mothers who are going to perform Sectio Caesarea surgery.
\end{abstract}

Keywords: guided imagery, sectio caesarea, anxiety level

\title{
PENDAHULUAN
}

Kehamilan merupakan satu periode dimana seorang wanita membawa embrio (fetus) di dalam rahimnya. Kehamilan manusia terjadi selama 40 minggu mulai waktu menstruasi terakhir dan kelahiran (38 minggu dari pembuahan) sehingga kehamilan juga disebut suatu episode dramatis terhadap kondisi biologis, perubahan psikologis dan adaptasi dari seorang wanita yang pernah mengalaminya (Kasdu dalam Janiwarty dan Pieter, 2009). Setiap wanita menginginkan persalinannya berjalan lancar dan dapat melahirkan bayi dengan sempurna. Persalinan bisa saja berjalan secara normal, namun tidak jarang proses persalinan mengalami hambatan dan harus dilakukan melalui operasi. Hal ini berarti janin dan ibu dalam keadaan gawat darurat dan hanya dapat diselamatkan jika persalinan dilakukan dengan jalan operasi Sectio caesarea (SC). 
Sectio caesarea (SC) adalah salah satu operasi bedah yang paling umum dilakukan di dunia saat ini sebagai salah satu cara untuk membantu proses kelahiran janin melalui insisi pada dinding abdomen (laparotomi) dan dinding rahim (histerektomi). Survei Global Kesehatan oleh WHO (2013) yang dituliskan dalam data statistik kesehatan dunia menyebutkan bahwa angka kejadian SC terbesar terdapat pada wilayah Amerika (36\%), wilayah Western Pasifik (24\%) dan wilayah Eropa (23\%). Sejalan dengan penelitian yang dilakukan oleh Osterman et al mengenai perubahan jumlah rata-rata kelahiran melalui SC di Amerika Serikat sejak tahun 1996 (19,7\%) menjadi 32,2\% pada tahun 2011. Peningkatan kejadian sectio caesarea tidak hanya terjadi di negara-negara maju saja, negara berkembang juga mendapatkan peningkatan yang signifikan, salah satunya negara Indonesia. Angka kejadian SC di Indonesia mengalami peningkatan pada tahun 2000 jumlah ibu bersalin dengan sectio caesarea 47,22\%, tahun 2001 sebesar 45,19\%, tahun 2002 sebesar 47,13\%, tahun 2003 sebesar 46,87\%, tahun 2004 sebesar 53,2\%, tahun 2005 sebesar $51,59 \%$, dan tahun 2006 sebesar 53,68\% dan tahun 2007 belum terdapat data yang signifikan, tahun 2009 sebesar sekitar 22,8\% (Karundeng, 2014).

Operasi adalah keadaan yang membutuhkan tindakan pembedahan. Dalam pelaksanaan operasi sangat beresiko, lebih dari 230 juta operasi mayor dilakukan setiap tahun di dunia, menyebabkan keadaan pasien saat operasi akan lemah, meningkatkan komplikasi setelah operasi dilakukan dan menyebabkan kematian (Pearse \& Moreno, 2012).

Operasi menjadi salah satu keadaan pemicu kecemasan dan stress, bahkan jika prosedur yang dilakukan masih tergolong kategori operasi minor.
Reaksi psikologi dan fisiologi pada prosedur operasi dan proses anestesi yang memungkinkan adanya respon kecemasan ditandai dengan naiknya tekanan darah, dan detak jantung. Pada periode preoperative pasien akan membutuhkan persiapan terutama berkaitan dengan tubuhnya, dimana hal tersebut menjadi faktor stressor sehingga respon kecemasan yang timbul berlebihan dan berdampak pada proses penyembuhan. Pada periode post operatif kecemasan bisa timbul dari kurangnya pengetahuan yang terjadi selama operasi, harapan yang tidak pasti tentang hasil dari operasi, dan dampak yang ditimbulkan setelah operasi seperti resiko operasi yang dibaca atau didengar oleh pasien, ketakutan yang berhubungan dengan nyeri, perubahan body image, serta prosedur diagnosa (Lewis, 2011). Selain itu terjadinya kecemasan pada pasien dikarenakan bagi pasien melakukan tindakan operasi adalah suatu keputusan yang besar. Pasien berharap ketika melakukan operasi seseorang akan bersama mereka dan melindungi mereka selama kurun waktu operasi yang memungkinkan, pasien tidak mempunyai kemampuan mengontrol dan menjaga dirinya sendiri. Pasien yang melakukan operasi sebagian besar berharap untuk mendapatkan support dan dorongan dari perawat perioperatif (Black \& Hawks, 2010).

Pada kondisi pre operasi diperlukan suatu managemen untuk meningkatkan pengetahuan pasien dan mengatasi kecemasan pasien saat menjalani operasi untuk mengurangi komplikasi seperti kematian, gagal ginjal, pendarahan postoperative (Lin et all, 2011).

Kecemasan pada pre operasi bisa ditangani dengan teknik relaksasi. Salah satu teknik relaksasi untuk mengurangi kecemasan adalah relaksasi imajinasi terbimbing (Guided imagery), tindakan ini bertujuan untuk meningkatkan 
kendali dan percaya diri serta mengurangi stress dan kecemasan yang pasien alami. Hal tersebut sejalan dengan hasil penelitian Ni Nengah Arini Murni (2014) di wilayah kerja Puskesmas Meninting Kecamatan Batu Layar Kabupaten Lombok Barat Provinsi Nusa Tenggara Barat (NTB) yang menyatakan bahwa guided imagery efektif dalam mengatasi masalah emosional pada ibu hamil yang mengalami peningkatan derajat kecemasan dan depresi.

Berdasarkan hasil

studi

pendahuluan pada tanggal 14 Mei 2020 di RSUD dr. R. SOEDJONO SELONG Kabupaten Lombok Timur didapatkan data jumlah pasien pre operasi sectio caesarea (SC) dari April - Juni didapatkan data sebanyak 103 orang, sedangkan dalam kurun waktu 1 bulan terakhir berjumlah 34 orang pasien pre operasi sectio caesarea (SC). Hasil wawancara peneliti dengan kepala ruangan dan perawat mengatakan tindakan yang sudah dilakukan perawat ruangan untuk mengurangi kecemasan pada pasien pre operasi sectio caesarea yaitu pemberian KIE. Teknik guided imagery masih belum diterapkan untuk mengurangi kecemasan pasien saat akan menjalani operasi sectio caesarea.

Berdasarkan uraian diatas peneliti tertarik untuk melakukan penelitian tentang "Pengaruh Pemberian Teknik Relaksasi Guided Imagery Terhadap Tingkat Kecemasan Pada Pasien Pre Operasi Sectio Caesarea Di RSUD Dr.R. SOEDJONO SELONG".

\section{BAHAN DAN METODE}

Desain penelitian yang digunakan dalam penelitian ini adalah preeksperimental dimana pemberian relaksasi guided imagery diberikan sebelum pasien melakukan operasi sectio caesarea. Penelitian ini dilakuakan di ruang nifas RSUD dr. R. Soedjono Selong pada tanggal 30 Juni 2020 s/d 14
Juli 2020. Populasi dalam penelitian ini adalah semua pasien pre operasi sectio caesarea di RSUD dr. R. SOEDJONO SELONG sebanyak 34 orang.

Besar sampel dalam penelitian ini sebanyak 31 orang responden dengan kriteria ibu primigravida yang akan melakukan operasi sectio caesarea (SC), teknik pengambilan sampel yang digunakan dalam penelitian ini adalah purposive sampling. Pengumpulan data tingkat kecemasan menggunakan DASS 21 dan lembar observasi. Kemudian data dianalisis menggunakan uji Wilcoxon Signed test.

\section{HASIL}

\section{A. Data Umum}

Tabel 1. Distribusi karaktristik responden berdasarkan umur dan pendidikan.

\begin{tabular}{|c|c|c|c|c|}
\hline No. & \multicolumn{2}{|c|}{ Karaktristik } & $\mathrm{n}$ & $\%$ \\
\hline \multirow{3}{*}{1.} & \multirow{3}{*}{ Umur } & $\begin{array}{c}\text { Remaja } \\
\text { Akhir (17- } \\
25)\end{array}$ & 8 & 25,8 \\
\hline & & $\begin{array}{c}\text { Dewasa } \\
\text { Awal (26- } \\
35)\end{array}$ & 20 & 64,5 \\
\hline & & $\begin{array}{c}\text { Dewasa } \\
\text { Akhir (36- } \\
45)\end{array}$ & 3 & 9,7 \\
\hline & Total & & 31 & 100,0 \\
\hline \multirow{6}{*}{2.} & \multirow{6}{*}{ Pendidikan } & SD & 7 & 22.6 \\
\hline & & SMP & 5 & 16.1 \\
\hline & & SMA & 10 & 32.3 \\
\hline & & D1 & 1 & 3.2 \\
\hline & & D3 & 1 & 3.2 \\
\hline & & $\mathrm{S} 1$ & 7 & 22.6 \\
\hline & Total & & 31 & 100,0 \\
\hline
\end{tabular}

Data pada tabel 1 menjelaskan bahwa kelompok umur didominasi oleh responden dengan umur dewasa awal yaitu sebanyak 20 orang $(64,5 \%)$. Sedangkan data terkait pendidikan responden didominasi oleh tingkat pendidikan SMA yaitu sebanyak 10 orang $(32,3 \%)$. 


\section{B. Data Khusus}

Tabel 2. Tingkat kecemasan sebelum diberikan relaksasi guided imagery.

\begin{tabular}{cccc} 
No & Kategori & $\mathrm{n}$ & $\%$ \\
\hline 1 & Normal & 0 & 0 \\
\hline 2 & Cemas ringan & 18 & 58.1 \\
\hline 3 & Cemas sedang & 12 & 38.7 \\
\hline 4 & Cemas berat & 1 & 3.2 \\
\hline 5 & Cemas sangat berat & 0 & 0 \\
\hline Total & & 31 & 100 \\
\hline
\end{tabular}

Data pada tabel 2 menjelaskan bahwa sebagian besar responden sebelum diberikan relaksasi guided imagery memiliki kecemasan ringan yaitu 18 responden $(58,1 \%)$.

\begin{tabular}{cccc} 
No & Kategori & $\mathrm{n}$ & $\%$ \\
\hline 1 & Normal & 29 & 93.5 \\
\hline 2 & Cemas ringan & 2 & 6.5 \\
\hline 3 & Cemas sedang & 0 & 0 \\
\hline 4 & Cemas berat & 0 & 0 \\
\hline 5 & Cemas sangat berat & 0 & 0 \\
\hline Total & & 31 & 100 \\
\hline
\end{tabular}

Tabel 3. Tingkat kecemasan sesudah diberikan relaksasi guided imagery.

Data pada tabel 3 menjelaskan bahwa sebagian besar responden sesudah diberikan relaksasi guided imagery memiliki kecemasan normal yaitu 29 responden $(96,8 \%)$.

C. Analisa Pengaruh Pemberian Teknik Relaksasi Guided Imagery Terhadap Tingkat Kecemasan Pada Pasien Pre Operasi Sectio Caesarea di Rsud Dr. R. Soedjono Selong

Tabel 4. Analisa uji Wilcoxon Signed test

\begin{tabular}{|c|c|c|c|c|c|}
\hline & & $\mathrm{N}$ & $\begin{array}{l}\text { Mean } \\
\text { Rank }\end{array}$ & $\begin{array}{c}\text { Sum of } \\
\text { Ranks }\end{array}$ & P Value \\
\hline \multirow[t]{3}{*}{$\begin{array}{l}\text { Post Test } \\
\text { Pre Test }\end{array}$} & $\begin{array}{l}\text { Negative } \\
\text { Ranks }\end{array}$ & $31^{\mathrm{a}}$ & 16.00 & 496.00 & \multirow{3}{*}{0,000} \\
\hline & $\begin{array}{l}\text { Positive } \\
\text { Ranks }\end{array}$ & $0^{\mathrm{b}}$ & .00 & .00 & \\
\hline & Ties & $0^{c}$ & & & \\
\hline
\end{tabular}

Data tabel 4 menjelaskan bahwa berdasarkan hasil analisa uji Wilcoxon signed ranks test dengan spss versi 25 diperoleh $\mathrm{n}$ atau jumlah data penelitian sebanyak 31 responden dan nilai $p$ value $=0,000$, hasil ini menunjukkan bahwa $\mathrm{p}$ Value $<\alpha$ $(0.000<0,05)$, artinya Ha diterima maka dapat disimpulkan bahwa ada pengaruh pemberian teknik relaksasi guided imagery terhadap tingkat kecemasan pada pasien pre operasi sectio caesarea.

\section{PEMBAHASAN}

\section{Tingkat kecemasan sebelum diberikan relaksasi guided imagery}

Hasil tabel 2 menunjukkan bahwa sebagian besar responden sebelum diberikan relaksasi guided imagery memiliki kecemasan ringan yaitu 18 responden $(58,1 \%)$. Hasil yang diperoleh dari kuesioner, skor tertinggi yaitu 49 pada item pertanyaan nomor 3 "Saya mengalami gemetar (contoh: di tangan)". Hasil dengan skor terendah yaitu 35 terdapat pada item nomor 2 "Saya mengalami kesulitan bernafas (contoh: bernafas cepat dan berat, sulit bernafas saat tidak ada aktivitas fisik)".

Menurut Hawari (2001) pada individu yang cemas, gejalanya didominasi oleh keluhan psikis (ketakutan dan kekhawatiran), tetapi dapat pula disertai keluhan somatis (fisik). Adapun gejala pada individu yang mengalami kecemasan adalah khawatir, bimbang, firasat buruk, takut akan pikirannya sendiri dan mudah tersinggung; merasa tegang, tidak tenang, gelisah, gerakan sering serba salah dan mudah terkejut; takut sendirian, takut keramaian dan banyak orang; gangguan pola tidur, mimpimimpi yang menegangkan; gangguan konsentrasi dan daya ingat; keluhan somatic seperti rasa sakit pada otot dan tulang, pendengaran berdengung (tinitus), berdebar-debar, sesak nafas, gangguan pencernaan, sakit kepala, dan sebagainya. Sejalan dengan penelitian yang sudah dilakukan oleh Nur 
Masruroh (2015) mengatakan bahwa tingkat kecemasan berpengaruh pada proses persalinan, sehingga menimbulkan kekhawatiran yang beranekaragam, seperti takut tidak bisa melahirkan normal, takut bayinya lahir cacat, takut bayinya tidak selamat, dan lain sebagainya.

\section{Tingkat kecemasan sesudah diberikan relaksasi guided imagery}

Hasil tabel 3 menunjukkan bahwa sebagian besar responden sesudah diberikan relaksasi guided imagery memiliki tingkat kecemasan normal yaitu 29 responden $(93,5 \%)$. Hasil yang diperoleh dari kuesioner, skor tertinggi yaitu 36 pada item pertanyaan nomor 1 "Saya menyadari mulut saya kering". Hasil dengan skor terendah yaitu 10 terdapat pada item nomor 2 "Saya mengalami kesulitan bernafas (contoh: bernafas cepat dan berat, sulit bernafas saat tidak ada aktivitas fisik)". Guided imagery didefinisikan sebagai penggunaan imajinasi yang membawa pikiran atau respon tubuh yang positif. Itu merupakan proses kognitif yang menggunakan indera penglihatan, suara, bau, rasa, sentuhan dan juga perasaan bergerak yang semuanya bersama menghasilkan perubahan regeneratif di pikiran dan tubuh (Alves, 2009). Guided imagery merupakan teknik yang menggunakan imajinasi seseorang untuk mencapai efek positif tertentu (Smeltzer, Bare, Hinkle, \& Cheever, 2010). Penelitian ini sejalan dengan penelitian yang dilakukan oleh Jon (2013) mengatakan bahwa guided imagery terbukti untuk menurunkan kecemasan karena berpengaruh dalam sistem kontrol fisiologi tubuh, memberikan relaksasi dan menghasilkan hormon endorphin untuk membuat tenang. Adapun respon klien saat diberikan relaksasi guided imagery sangat kooperatif dan dengan respon tubuh klien sangat tenang, penelitian yang dilakukan oleh Aprianto (2015) tentang efektifitas teknik relaksasi imajinasi terbimbing dan nafas dalam terhadap penurunan kecemasan pada pasien pre operasi, diperoleh hasil ada pengaruh teknik relaksasi imajinasi terbimbing terhadap penurunan kecemasan pasien pre operasi di RSUD RA Kartini Jepara dengan $(p$-value $=0,000)$.

\section{Analisa pengaruh pemberian teknik relaksasi guided imagery terhadap tingkat kecemasan pada pasien pre operasi sectio caesarea}

Berdasarkan tabel 4 menunjukkan bahwa sebelum diberikan perlakuan 0 responden $(0 \%)$ dengan kecemasan normal dan setelah diberikan perlakuan responden dengan tingkat kecemasan normal sebanyak 29 orang $(93,5 \%)$, responden dengan kecemasan ringan sebelum diberikan perlakuan yaitu sebanyak 18 responden $(58,1 \%)$ dan setelah diberikan perlakuan sebanyak 2 responden $(6,5 \%)$, responden dengan kecemasan sedang sebelum diberikan perlakuan yaitu sebanyak 12 orang dan setelah diberikan perlakuan sebanyak 0 $(0 \%)$ responden, responden dengan kecemasan berat sebelum diberikan perlakuan yaitu sebanyak 1 responden $(3,2)$ dan setelah diberikan perlakuan sebanyak 0 responden $(0 \%)$, responden dengan kecemasan sangat berat sebelum diberikan perlakuan yaitu 0 responden $(0 \%)$ dan setelah diberikan perlakuan sebanyak 0 responden $(0 \%)$.

Hasil dalam penelitian ini menunjukan rata-rata skor pada masingmasing item mengalami penurunan. Item nomor 3 dengan skor 49 pada saat pre test setelah diberikan perlakuan guided imagery menurun menjadi 11. Hasil terendah pada saat pre test terdapat pada item nomor 2 dengan skor 35 setelah diberikan perlakuan guided imagery menurun menjadi 10 .

Hasil uji Wilcoxon signed ranks test dengan spss versi 25 diperoleh $\mathrm{n}$ atau 
jumlah data penelitian sebanyak 31 responden dan nilai $\mathrm{p}$ value $=0,000$. Maka $\mathrm{p}$ Value $<\alpha(0.000<0,05)$, artinya Ha diterima maka dapat disimpulkan bahwa ada pengaruh pemberian teknik relaksasi guided imagery terhadap tingkat kecemasan pada pasien pre operasi sectio caesarea.

Hasil penelitian ini sejalan dengan teori yang dikemukakan oleh Guyton dan Hall (2008), bahwa guided imagery merupakan suatu teknik yang menuntut seseorang untuk membentuk sebuah bayangan/imajinasi tentang hal-hal yang disukai. Hal-hal yang disukai dianggap sebagai sinyal penting oleh hipokampus sehingga diproses menjadi memori, dengan membayangkan hal-hal yang disukai maka hormon 'kebahagiaan' (beta endorfin) akan berproduksi.

Beta-endorfin kemudian akan berperan dalam menghambat $\mathrm{ACTH}$ (Adrenocorticotropic Hormone) yang diproduksi oleh hipofisis dan akan menghambat diproduksinya kortison dan berbagai hormone stress lainnya sehingga akan mengurangi stress atau kecemasan. Membayangkan waktu dan tempat favorit dalam semua keindahan sensori pemandangan, suara, bau, perasaan dapat menghasilkan respon emosional yang positif sebagai distraksi yang menyenangkan untuk mengalihkan perhatian dari suatu ketidaknyamanan ataupun rasa sakit (Naparstek, 2007). Oleh karena itu, dengan memberikan jeda atau mengalihkan pikiran individu yang merasakan ketidaknyamanan berupa pikiran-pikiran negatif (kecemasan) saat kehamilan dan berfokus pada hal-hal yang menyenangkan, maka kecemasan tersebut akan berangsur-angsur menurun. Komponen guided imagery melibatkan indera berupa penciuman, pendengaran, pengecap, dan perasa untuk dapat mengubah pemikiran, emosi, serta perilaku seseorang, melalui pemanfaatan indera tersebut dapat mempengaruhi perspektif personal individu terhadap dirinya ataupun lingkungan sekitar (Nguyen, 2012).

\section{SIMPULAN}

Berdasarkan hasil penelitian yang telah dilakukan, didapatkan hasil yang signifikan yaitu terdapat pengaruh pemberian teknik relaksasi guided imagery terhadap tingkat kecemasan pada pasien pre operasi sectio caesarea di RSUD dr. R. Soedjono Selong. Peneliti berharap relaksasi guided imagery dapat menjadi salah satu cara untuk mengurangi tingkat kecemasan pasien sebelum melakukan operasi. 
DAFTAR PUSTAKA

Bachri, Syamsul, Zainul Cholid, Abdul Rochim. (2017). Perbedaan Tingkat Kecemasan Pasien Berdasarkan Usia, Jenis Kelamin, Tingkat Pendidikan dan Pengalaman Pencabutan Gigi Di RSGM FKG Universitas Jember. e-Jurnal Pustaka Kesehatan: Universitas Jember.

Bare BG., Smeltzer SC. 2010. Buku Ajar Keperawatan Medikal Bedah. Jakarta : EGC. Hal : 45-47.

Black, J.M., \& Hawks, J.H. 2010. Medical Surgical Nursing (8th Ed). Singapore: Saunder Elseiver. Clinical Problems Volume 2. Mosby: ELSEVIER.

Hawari, Dadang. 2001. Manajemen Stress Cemas dan Depresi. Jakarta : Balai penerbitan FKUI.

Karundeng, dkk. 2014. Faktor-faktor yang berperan meningkatnya angka kejadian sectio caesarae. (Diakses tanggal 13 September 2019) Didapat dari :

https://ejournal.unsrat.ac.id/index.php/jk $\mathrm{p} /$ article/view/4052.

Lewis, et al. 2011. Medical Surgical Nursing Assesment and Management of Clinical Problems Volume 2. Mosby: ELSEVIER.

Lin, A.J., Liao, C., Chang, C,C., Chang, H., \& Chen, T.L. (2011). Postoperative Adverse Outcomes In Intellectually Disabled Surgical Patients: A Nationwide Population Based Study . Journal of PLos ONE . 6(10): e26977. DOI : 10.1371/journal.pone.0026977.

Lukman. 2009. Asuhan keperawatan pada klien dengan gangguan system musculoskeletal. Jakarta: Salemba Medika.

Luís Alves Apóstolo. 2009. The Effects of Guided Imagery on Comfort, Depression, Anxiety, and Stress of Psychiatric Inpatients with
Depressive Disorders. (Diaksestanggal 10 Agustus 2020). Didapat dari https://www.researchgate.net/publi cation/38113566_The_Effects_of_ Guided_Imagery_on_Comfort_De pression_Anxiety_and_Stress_of_ Psychiatric_Inpatients_with_Depre ssive_Disorders.

Naparstek, B. 2007. Guided Imagery: A Best Practice for Pregnancy \& Childbirth. International Journal of Childbirth Education, vol 22, no.3, h.4-8.

Nguyen, Tong Thi-Ngoc. 2012. Utilization of Guided Imagery whithin the Fouurt Phases of Adlerian Therapy. Research Paper. The Faculty of the Adler Graduate School.

Ni Nengah Arini Murni. (2014). Pengaruh Latihan Relaksasi Guided Imagery And Music (GIM) Pada Kelas Ibu Terhadap Derajat Kecemasan Ibu Hamil Menghadapi Persalinan Pertama: Studi di Puskesmas Meninting Kabupaten Lombok Barat.Volume 8. nomor 1. Jurnal Kesehatan Prima.

Nur Masruroh. 2015. Pengaruh kecemasan ibu terhadap terhadap proses persalinan kala 1 Fase aktif di BPS Atik SuharijatiSurabaya.Volume 8.Journal of Health Sciences. 